\title{
Cu-catalyzed trifluoromethylation of aryl iodides with trifluoromethylzinc reagent prepared in situ from trifluoromethyl iodide
}

\author{
Yuzo Nakamura, Motohiro Fujiu, Tatsuya Murase, Yoshimitsu Itoh, \\ Hiroki Serizawa, Kohsuke Aikawa and Koichi Mikami ${ }^{*}$
}

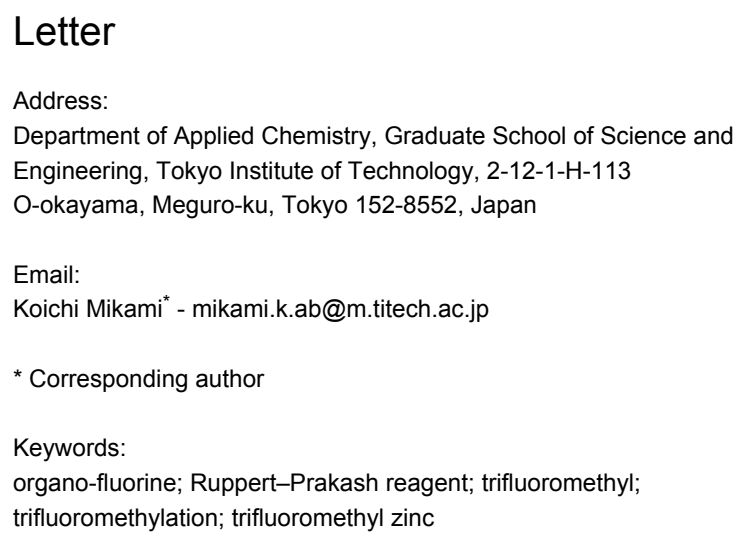

\author{
Beilstein J. Org. Chem. 2013, 9, 2404-2409. \\ doi:10.3762/bjoc. 9.277 \\ Received: 02 September 2013 \\ Accepted: 10 October 2013 \\ Published: 08 November 2013 \\ This article is part of the Thematic Series "Organo-fluorine chemistry III" \\ and is dedicated to the memory of the late Professor Nobuo Ishikawa on \\ the occasion of his 23 rd Kai-Ki. \\ Guest Editor: D. O'Hagan
}

(C) 2013 Nakamura et al; licensee Beilstein-Institut. License and terms: see end of document.

\begin{abstract}
The trifluoromethylation of aryl iodides catalyzed by copper(I) salt with trifluoromethylzinc reagent prepared in situ from trifluoromethyl iodide and $\mathrm{Zn}$ dust was accomplished. The catalytic reactions proceeded under mild reaction conditions, providing the corresponding aromatic trifluoromethylated products in moderate to high yields. The advantage of this method is that additives such as metal fluoride (MF), which are indispensable to activate silyl groups for transmetallation in the corresponding reactions catalyzed by copper salt by using the Ruppert-Prakash reagents $\left(\mathrm{CF}_{3} \mathrm{SiR}_{3}\right)$, are not required.
\end{abstract}

\section{Introduction}

Organo-fluorine compounds have received considerable attention in the fields of biomedical chemistry, agrochemistry, and organic material science due to their unique chemical, biological, and physical properties [1-6]. Particularly, trifluoromethylated compounds can be widely employed as one of the most effective analogues of bioactive compounds, because the trifluoromethyl group enhances the metabolic stability, lipophilicity, and bioavailability of these compounds [7]. As a result, trifluoromethylated compounds have been efficiently synthesized by both building-block methods which employ trifluoromethylated substrates and direct methods which employ trifluoromethyl reagents [7-9]. However, a nucleophilic trifluoromethylation by trifluoromethyl organometallic reagents such as lithium and magnesium, which are widely utilized in non-fluorine organic synthesis, cannot be used. These trifluoromethyl metal reagents are generally too unstable to prepare 
even at low temperature because of facile $\alpha$-fluoro elimination generating the singlet difluoromethylene $\left(: \mathrm{CF}_{2}\right)$ [10]. In contrast, trifluoromethylsilyl counterparts, so-called Ruppert-Prakash reagents $\left(\mathrm{CF}_{3} \mathrm{SiR}_{3}\right)$, are highly stable, but reactive in the presence of fluoride, and hence the most versatile nucleophilic trifluoromethyl reagents [11,12]. The trifluoromethylzinc reagent $\left(\mathrm{Zn}\left(\mathrm{CF}_{3}\right) \mathrm{Br} \cdot 2 \mathrm{DMF}\right)$, a stable solid, can also be used for the trifluoromethylation of aryl iodides, while stoichiometric amounts of copper(I) bromide are required to afford the more reactive trifluoromethyl copper $\left(\mathrm{CuCF}_{3}\right)$ species by transmetallation $[13,14]$. However, these reagents are generally prepared from trifluoromethyl bromide $\left(\mathrm{CF}_{3} \mathrm{Br}\right)$, whose production is now prohibited because of the ozone depleting effect [15]. On the other hand, the trifluoromethylzinc reagent $\left(\mathrm{Zn}\left(\mathrm{CF}_{3}\right) \mathrm{I}\right)$ formed in situ from trifluoromethyl iodide $\left(\mathrm{CF}_{3} \mathrm{I}\right)$ as an alternative trifluoromethyl source is utilized for trifluoromethylation reactions $[10,16]$. The preparation of the reagent followed by the reactions, however, requires ultrasonic irradiation and thus lacks reproducibility [16]. Therefore, the direct and reproducible preparation of the trifluoromethylzinc reagent and its application to trifluoromethylation reactions pose a particular challenge. Recently, Daugulis and co-workers reported the trifluoromethylation of aryl iodide catalyzed by copper(I) chloride with $\mathrm{Zn}\left(\mathrm{CF}_{3}\right)_{2}$ prepared in situ from $\mathrm{TMP}_{2} \mathrm{Zn}$ and fluoroform $\left(\mathrm{CHF}_{3}\right)$, but only one substrate was investigated to provide the trifluoromethylated product only in a moderate yield [17]. As described above, much of the area of catalytic trifluoromethylations with trifluoromethylzinc reagent has not been explored yet, compared to the area of catalytic trifluoromethylations with the Ruppert-Prakash reagents [7,11,12,18-21]. Herein, we report the trifluoromethylations of aryl iodides catalyzed by copper(I) salt with trifluoromethylzinc reagent prepared in situ from $\mathrm{CF}_{3} \mathrm{I}$ and $\mathrm{Zu}$ dust. The trifluoromethylated aromatic products are privileged skeletal key compounds in pharmaceutical science as shown in Mefloquine $\left(\operatorname{Lariam}^{\circledR}\right)$, Fluoxetine $\left(\operatorname{Prozac}^{\circledR}\right)$, Leflunomide (Arava ${ }^{\circledR}$ ), Celecoxib (Celebrex ${ }^{\circledR}$ ), Bicalutamide $\left(\right.$ Casodex $\left.{ }^{\circledR}\right)$, Aprepitant $\left(\right.$ Emend $\left.^{\circledR}\right)$, and Nilutamide (Nilan$\left.\operatorname{dron}^{\circledR}\right)$.

\section{Results and Discussion}

The preparation of the trifluoromethylzinc reagent $\mathrm{Zn}\left(\mathrm{CF}_{3}\right) \mathrm{I}$ was initially examined in the context of the in situ $\mathrm{Cu}$-catalyzed trifluoromethylation of aryl iodide $\mathbf{1}$ under various conditions. The results of the reaction are summarized in Table 1. After $\mathrm{Zn}\left(\mathrm{CF}_{3}\right) \mathrm{I}$ was prepared in situ by the treatment of $\mathrm{CF}_{3} \mathrm{I}$ (ca. 5 equiv) with $\mathrm{Zn}$ dust (2 equiv) [22] in various solvents at room temperature for 2 hours, the reactions were explored by adding a catalytic amount of copper(I) salt and 1,10-phenanthroline (phen) [18-21] followed by aryl iodide 1a. In this catalytic

Table 1: Copper-catalyzed trifluoromethylation of aryl iodide 1a.

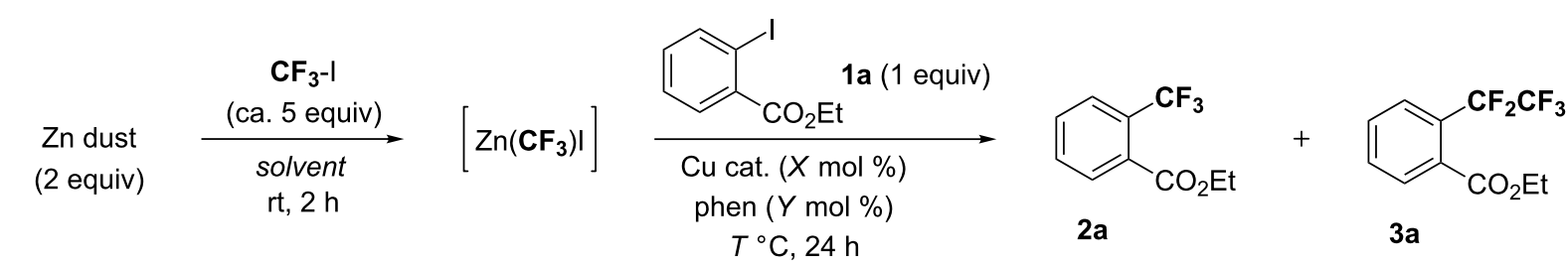

\begin{tabular}{|c|c|c|c|c|c|}
\hline entry & solvent & Cu cat. & $(\mathrm{X}, \mathrm{Y})$ & $T$ & $\%$ yield $(2 a / 3 a)^{a}$ \\
\hline 1 & toluene & Cul & 10,20 & 50 & n.r. \\
\hline 2 & THF & Cul & 10,20 & 50 & n.r. \\
\hline 3 & $\mathrm{CH}_{3} \mathrm{CN}$ & Cul & 10,20 & 50 & $1 / 1$ \\
\hline 4 & DMSO & Cul & 10,20 & 50 & $2 / 0$ \\
\hline 5 & NMP & Cul & 10,20 & 50 & n.r. \\
\hline 6 & DMF & Cul & 10,20 & 50 & $44 / 8$ \\
\hline 7 & DMPU & Cul & 10,20 & 50 & $70 / 9$ \\
\hline 8 & DMPU & Cul & 10,10 & 50 & $93 / 7$ \\
\hline 9 & DMPU & Cul & 10,10 & $\mathrm{rt}$ & $61 / 2$ \\
\hline 10 & DMPU & Cul & 10,10 & 40 & $67 / 5$ \\
\hline 11 & DMPU & Cul & 10,10 & 65 & $77 / 10$ \\
\hline 12 & DMPU & $\mathrm{CuCl}$ & 10,10 & 50 & $92 / 8$ \\
\hline 13 & DMPU & CuTC & 10,10 & 50 & $92 / 6$ \\
\hline 14 & DMPU & Cul & 2,2 & 50 & $95 / 2$ \\
\hline
\end{tabular}

aYields were determined by ${ }^{19} \mathrm{~F}$ NMR analysis by using benzotrifluoride as an internal standard. 
system, solvents showed significant effects on the preparation and catalytic reactivity of $\mathrm{Zn}\left(\mathrm{CF}_{3}\right) \mathrm{I}$. No reaction was observed in less polar solvents such as toluene (Table 1, entry 1). Even in THF, $\mathrm{CH}_{3} \mathrm{CN}$, DMSO, and NMP, the desired product 2a was barely or not at all obtained (Table 1, entries 2-5). Formation of $\mathrm{Zn}\left(\mathrm{CF}_{3}\right) \mathrm{I}$ and reaction in DMF were found to proceed only with $44 \%$ yield (Table 1, entry 6). Replacement of DMF with DMPU provided the trifluoromethylated product 2a in $70 \%$ yield, along with the undesired pentafluoroethylated product 3a in $9 \%$ yield (Table 1, entry 7).

The product 3a should be derived from $\mathrm{CuCF}_{2} \mathrm{CF}_{3}$ generated by an insertion of difluoromethylene $\left(: \mathrm{CF}_{2}\right)$ decomposed from $\mathrm{CuCF}_{3}$ into $\mathrm{CuCF}_{3}$ [23]. Decreasing the loading of phen, the yield of product $\mathbf{2 a}$ was further increased to exceed the level of $90 \%$ yield (Table 1 , entry 8 ). The reaction was promoted even under the milder reaction conditions at room temperature $(61 \%$ yield), but the highest yield was obtained at $50{ }^{\circ} \mathrm{C}$ (Table 1 , entry 8 vs entries 9-11). A further change from $\mathrm{CuI}$ to $\mathrm{CuCl}$ and CuTC led to comparable results (Table 1, entries 12 and 13). With only a $2 \mathrm{~mol} \%$ loading of both $\mathrm{CuI}$ and phen ligand, the yield of 2a was further increased to a higher level (95\% yield) along with an increased selectivity with only $2 \%$ yield of $\mathbf{3 a}$ (Table 1, entry 14).
The ligand effect was further investigated in DMPU at $50{ }^{\circ} \mathrm{C}$ and phen was preferable to other diamine ligands (Table 2 , entries 1-3 vs entry 4). Surprisingly, even in the absence of phen, it was found that the reaction smoothly proceeded to give a comparably high yield of product $\mathbf{2 a}$ (Table 2, entry 6). The reaction with a shorter reaction time of 2 hours indicated that the phen ligand slightly accelerated the reaction by the coordination to $\mathrm{CuCF}_{3}$ species, when compared to the reactions performed without the ligand (Table 2, entry 5 (78\% yield) vs entry $6(68 \%$ yield $))$. In the absence of $\mathrm{CuI}$, no coupling product was obtained even in the presence of phen (Table 2, entries 7 and 8).

With the reaction conditions established in DMPU at $50{ }^{\circ} \mathrm{C}$ in the presence of a catalytic amount of $\mathrm{CuI}$ and phen, the scope and limitation of this method were evaluated. The results are shown in Figure 1. The use of the electron-deficient aryl iodides 1b-f bearing nitrile, nitro, formyl, and trifluoromethyl groups led to the corresponding products $\mathbf{2 b}-\mathbf{f}$ in moderate to high yields. The reactions of heteroaryl iodides $\mathbf{1 g - i}$ were also catalyzed to provide the corresponding products $2 \mathbf{g}-\mathbf{i}$ in good to

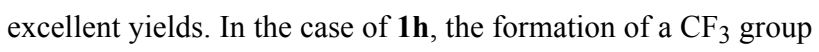
occurred only at the position of iodide, and bromide remained intact during the course of reaction. It was found that an

Table 2: Effect of ligands in copper-catalyzed trifluoromethylation.

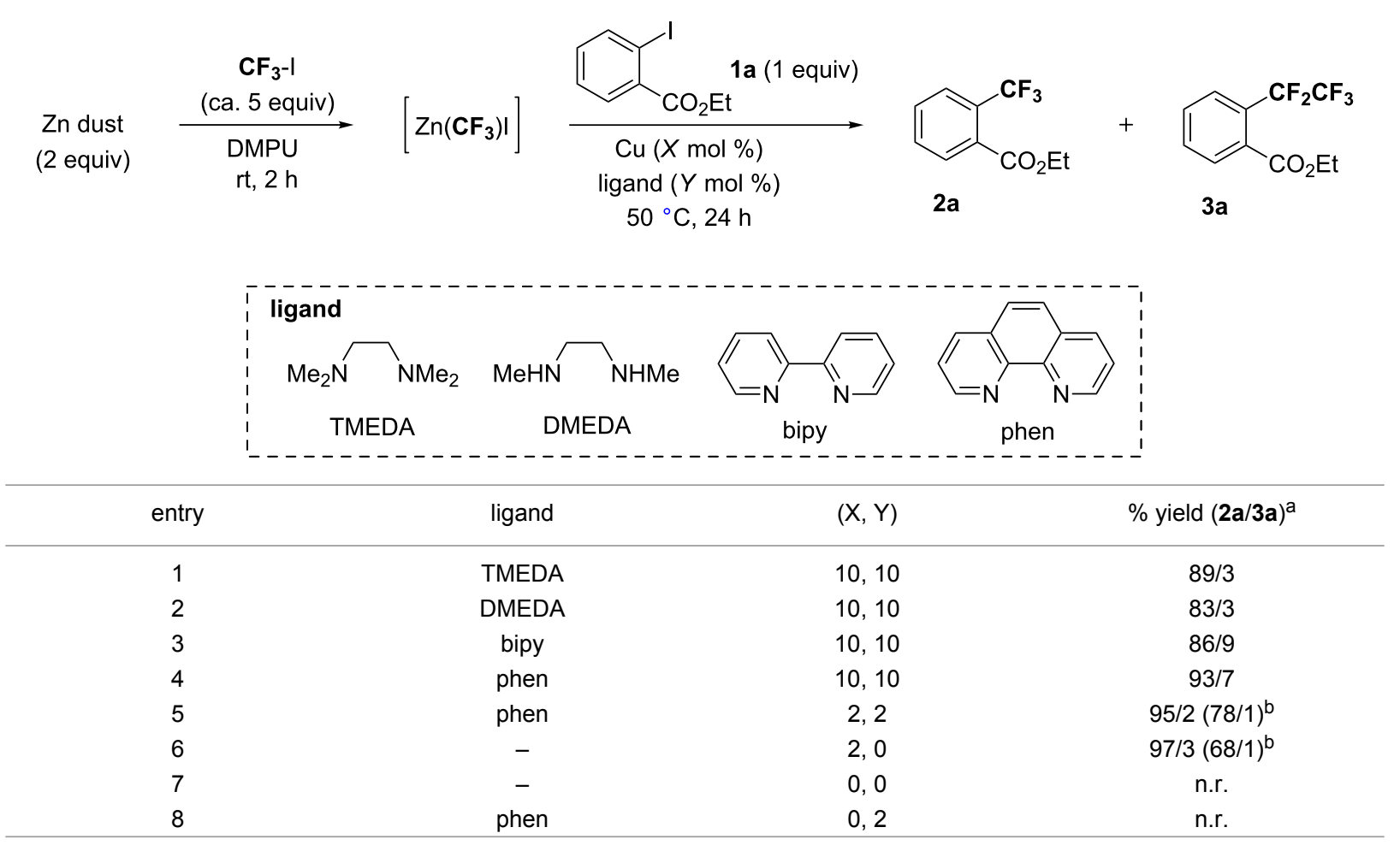

aYields were determined by ${ }^{19} \mathrm{~F}$ NMR analysis by using benzotrifluoride as an internal standard. ${ }^{b}$ Values in parentheses are yields obtained with a reaction time of 2 hours. 
<smiles>N#Cc1ccc(C(F)(F)F)cc1</smiles>

2b, $60 \%(28 \%)^{\text {a }}$<smiles>N#Cc1ccc(C(F)(F)F)cc1C(F)(F)F</smiles>

2c, $78 \%\left(73 \%^{\mathrm{c}}\right)^{\mathrm{b}}$<smiles>O=[N+]([O-])c1ccc(C(F)(F)F)cc1</smiles>

2d, $80 \%(44 \%)^{a}$<smiles>O=[N+]([O-])c1ccc(C(F)(F)F)c([N+](=O)[O-])c1</smiles><smiles>O=Cc1ccc(C(F)(F)F)cc1</smiles>

2e, $90 \%(81 \%)^{b}$ 2f, $44 \%(40 \%)^{b}$<smiles>FC(F)(F)c1ccccn1</smiles>

2 g, $90 \%(96 \%)^{b}$
$\mathrm{Br}$<smiles>Cc1ccc(C(F)(F)F)nc1</smiles><smiles>FC(F)(F)c1cnccn1</smiles>

2i, $76 \%(84 \%)^{b}$<smiles>COc1ccc(C(F)(F)F)cc1</smiles>

2j, $6 \%(5 \%)^{b}$

Figure 1: Copper-catalyzed trifluoromethylation of various aryl iodides. Yields were determined by ${ }^{19} \mathrm{~F}$ NMR analysis by using benzotrifluoride as an internal standard. Values in parentheses are yields obtained under the reaction conditions without phen. Conditions: $\mathrm{CF}_{3} \mathrm{l}(2.5 \times \mathrm{X}$ equiv) and $\mathrm{Zn}$ dust (X equiv) in DMPU, then $\mathrm{Cul}$ ( $\mathrm{Y} \mathrm{mol} \%$ ), phen ( $\mathrm{Y} \mathrm{mol} \mathrm{\% )} \mathrm{and} 1$ (1 equiv) at $50{ }^{\circ} \mathrm{C}$ for $t$ hours. ${ }^{\mathrm{a}} \mathrm{X}=4, \mathrm{Y}=2, t=48$. ${ }^{\mathrm{b}} \mathrm{X}=2, \mathrm{Y}=10, t=24$. ${ }^{\mathrm{C}} \mathrm{lsolated}$ yields: $\mathbf{2 c}, 70 \%$; $\mathbf{2 h}, 90 \%$.

increase of the yield in the presence of the phen ligand depends on the particular substrate, while the yields were within the same range except for $\mathbf{2 b}$ and $\mathbf{2 d}$. Unfortunately, aryl iodide $\mathbf{1 j}$ bearing the electron-donating methoxy substituent extremely decreased the reactivity, even when increasing the catalytic amounts of $\mathrm{CuI}$ and phen.

In order to gain an insight into each step of the catalytic trifluoromethylation with a trifluoromethylzinc reagent, a ${ }^{19} \mathrm{~F}$ NMR analysis in DMF and DMPU was performed (Scheme 1). At the initial stage, $\mathrm{Zn}\left(\mathrm{CF}_{3}\right) \mathrm{I}$ which readily causes a Schlenk equilibrium with $\mathrm{Zn}\left(\mathrm{CF}_{3}\right)_{2}$ and $\mathrm{ZnI}_{2}$ [14,24] was prepared in situ from $\mathrm{CF}_{3} \mathrm{I}$ and $\mathrm{Zn}$ dust in $60-80 \%$ yields in both solvents. The addition of $\mathrm{CuI}$ ( 0.2 equiv) to a DMPU solution of $\mathrm{Zn}\left(\mathrm{CF}_{3}\right) \mathrm{I}$ led to the transmetallation of the $\mathrm{CF}_{3}$ group from zinc to copper even at room temperature. Two singlet peaks of the cuprate species, $\left[\mathrm{Cu}\left(\mathrm{CF}_{3}\right) \mathrm{I}\right]^{-}(-29.7 \mathrm{ppm})$ and $\left[\mathrm{Cu}\left(\mathrm{CF}_{3}\right)_{2}\right]^{-}(-31.9 \mathrm{ppm})$ were observed in $12 \%$ and $1 \%$ yields, respectively $[23,25,26]$. By replacing DMPU with DMF as a solvent, the transmetallation was found to be less efficient than in DMPU. Moreover, the inactive copper species $\left[\mathrm{Cu}\left(\mathrm{CF}_{3}\right)_{4}\right]^{-}$ $(-34.8 \mathrm{ppm})$ [27] was obtained. The neutral $\mathrm{CuCF}_{3}$ species ( $-26.3 \mathrm{ppm})$, which formed by the direct cupration of fluoroform in DMF [28] and was active even with aryl iodides bearing electron-donating substituents such as $\mathbf{1 j}$ [28-30], was not observed in both solvents. Thus, the addition of aryl iodide 1a led to the formation of the trifluoromethyl coupling product 2a $(-59.8 \mathrm{ppm})$ even in the absence of phen, involving the consumption of the cuprates $\left[\mathrm{Cu}\left(\mathrm{CF}_{3}\right) \mathrm{I}\right]^{-}$and $\left[\mathrm{Cu}\left(\mathrm{CF}_{3}\right)_{2}\right]^{-}$. The use of DMF as a solvent led to a gradual increase of the

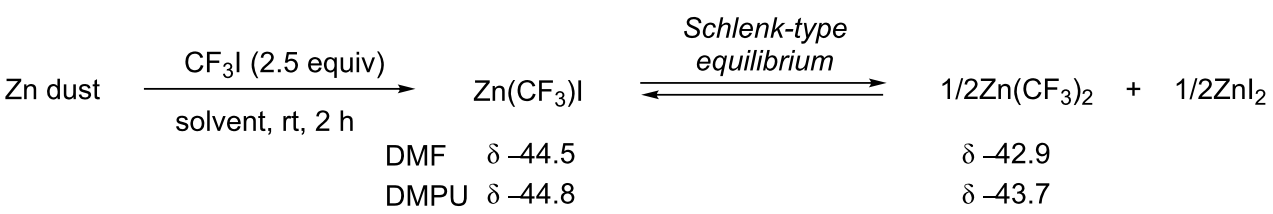

\begin{tabular}{|c|c|c|c|c|c|c|}
\hline \multirow{2}{*}{$\mathrm{Zn}\left(\mathrm{CF}_{3}\right) \mathrm{I}$} & Cul (0.2 equiv) ${ }^{a}$ & \multirow{2}{*}[\mathrm{Cu}(\mathrm{CF}_{3}){}^{\prime}]{$^{\ominus}$} & \multirow[b]{2}{*}{+} & \multirow{2}{*}[\mathrm{Cu}(\mathrm{CF}_{3})_{2}]{$^{\ominus}$} & \multirow[b]{2}{*}{+} & \multirow{2}{*}{$\begin{array}{c}{\left[\mathrm{Cu}\left(\mathrm{CF}_{3}\right)_{4}\right]^{\Theta}} \\
\text { inactive }\end{array}$} \\
\hline & solvent, rt, $5 \mathrm{~min}$ & & & & & \\
\hline & DMF & $\delta-29.4(2 \%)^{\mathrm{b}}$ & & $\delta-31.6(<1 \%)^{b}$ & & $\delta-34.8(1 \%)^{\mathrm{b}}$ \\
\hline & DMPU & $\delta-29.7(12 \%)^{b}$ & & $\delta-31.9(1 \%)^{\mathrm{b}}$ & & not observed \\
\hline
\end{tabular}

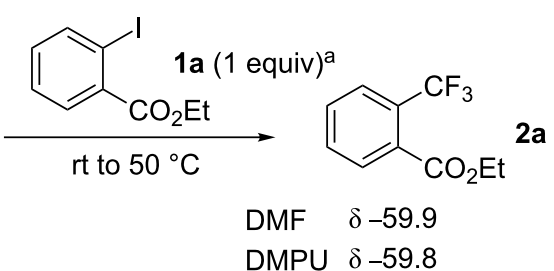


peak assigned as inactive $\left[\mathrm{Cu}\left(\mathrm{CF}_{3}\right)_{4}\right]^{-}$during the course of the reaction.

The mechanism of the coupling reaction can thus be visualized by the following catalytic cycle (Scheme 2). At the first step, the transmetallation of the $\mathrm{CF}_{3}$ group to $\mathrm{CuI}$ from $\mathrm{Zn}\left(\mathrm{CF}_{3}\right) \mathrm{I}$ or $\mathrm{Zn}\left(\mathrm{CF}_{3}\right)_{2}$ affords the active cuprate species, $\left[\mathrm{Cu}\left(\mathrm{CF}_{3}\right) \mathrm{X}\right]^{-}(\mathrm{X}=$ $\mathrm{I}, \mathrm{CF}_{3}$ ). Subsequently, the oxidative addition to the cuprate of aryl iodide $\mathbf{1}$, and the reductive elimination gives the desired cross-coupling product 2 together with the formation of $\mathrm{ZnI}_{2}$.

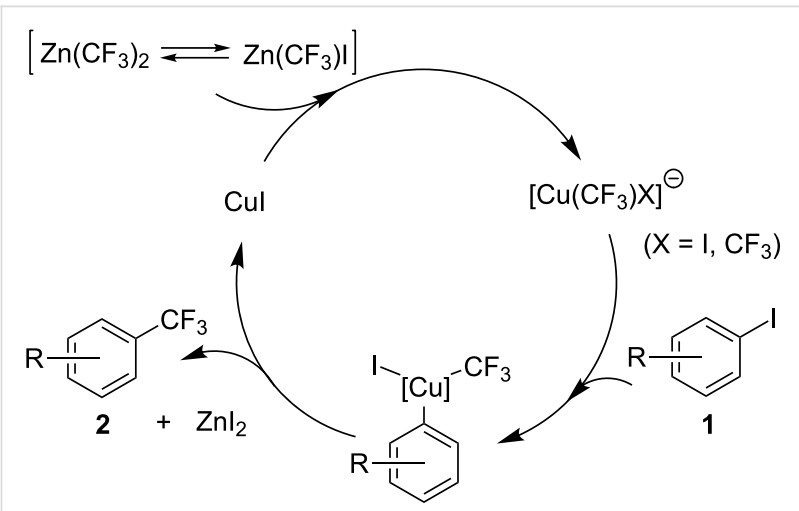

Scheme 2: Proposed mechanism of copper-catalyzed trifluoromethylation.

\section{Conclusion}

In summary, we succeeded in the aromatic trifluoromethylation catalyzed by copper(I) salt with a trifluoromethylzinc reagent prepared in situ from trifluoromethyl iodide and $\mathrm{Zn}$ dust in DMPU. The catalytic reaction proceeded to provide moderate to high yields and a high selectivity of the trifluoromethylated product under mild reaction conditions. The advantage of this catalytic reaction is that additives such as metal fluoride (MF), which are indispensable to activate silyl substituents for the transmetallation in the corresponding catalytic reactions by using the Ruppert-Prakash reagents, are not necessary. Additionally, with some substrates, the reaction conditions without a ligand led to higher yields than reaction conditions with a ligand such as 1,10-phenanthroline. Further studies on highly efficient trifluoromethylation and difluoromethylation reactions with trifluoromethylzinc reagents are under way.

\section{Experimental}

\section{Typical procedure for copper-catalyzed trifluoromethylation of aryl iodide}

To the suspension of zinc powder (without activation, $65.4 \mathrm{mg}$, $1.0 \mathrm{mmol}$, Aldrich $99.995 \%$ purity) in DMPU $(0.5 \mathrm{~mL})$, trifluoromethyl iodide (ca. $2.5 \mathrm{mmol}$, sufficiently dissolved in the solution) was added at room temperature under argon atmosphere. After the solution was stirred for $2 \mathrm{~h}$ at room tempera- ture, $\mathrm{CuI}$ (1.9 mg, $0.01 \mathrm{mmol}, 2 \mathrm{~mol} \%), 1.10$-phenanthroline (1.8 $\mathrm{mg}, 0.01 \mathrm{mmol}, 2 \mathrm{~mol} \%)$, and then aryl iodide $1 \mathrm{a}$ (138.0 $\mathrm{mg}, 0.5 \mathrm{mmol}$ ) were added. The reaction mixture was stirred at $50{ }^{\circ} \mathrm{C}$ for $24 \mathrm{~h}$. After cooling to room temperature, the yield of product $2 \mathbf{a}$ was determined by ${ }^{19} \mathrm{~F}$ NMR analysis by using benzotrifluoride (BTF) as an internal standard. Except for 2c, all trifluoromethylated products 2 exhibited the same ${ }^{1} \mathrm{H}$, ${ }^{13} \mathrm{C}$, and ${ }^{19} \mathrm{~F}$ NMR spectra as reported before [14,17,29,31-36].

\section{2,4-Bis(trifluoromethyl)benzonitrile (2c)}

To the suspension of zinc powder (without activation, $65.4 \mathrm{mg}$, $1.0 \mathrm{mmol}$, Aldrich $99.995 \%$ purity) in DMPU (0.5 mL), trifluoromethyl iodide (ca. $2.5 \mathrm{mmol}$, sufficiently dissolved in the solution) was added at room temperature under argon atmosphere. The solution was stirred for $2 \mathrm{~h}$, and $\mathrm{CuI}(9.5 \mathrm{mg}$, $0.05 \mathrm{mmol}, 10 \mathrm{~mol} \%$ ) and 4-iodo-2-(trifluoromethyl)benzonitrile (1c, $148.5 \mathrm{mg}, 0.5 \mathrm{mmol})$ were added. The reaction mixture was stirred at $50{ }^{\circ} \mathrm{C}$ for $24 \mathrm{~h}$. The reaction mixture was quenched with $\mathrm{H}_{2} \mathrm{O}(5 \mathrm{~mL})$, and then $\mathrm{Et}_{2} \mathrm{O}(5 \mathrm{~mL})$ was added. After filtration over celite, the organic layer was separated, and the aqueous layer was extracted with $\mathrm{Et}_{2} \mathrm{O}(5 \mathrm{~mL} \times 3)$. The combined organic layer was washed with brine $(10 \mathrm{~mL})$, dried over $\mathrm{Na}_{2} \mathrm{SO}_{4}$, and evaporated. The resulting crude product was purified by silica gel column chromatography (pentane/Et ${ }_{2} \mathrm{O}$ 9:1) to give the product $2 \mathrm{c}(83 \mathrm{mg}, 70 \%$ yield) as a colorless liquid. ${ }^{1} \mathrm{H}$ NMR $\left(300 \mathrm{MHz}, \mathrm{CDCl}_{3}\right) \delta 8.06(\mathrm{~s}, 1 \mathrm{H}), 8.03(\mathrm{~d}, J=$ $8.2 \mathrm{~Hz}, 1 \mathrm{H}), 7.98(\mathrm{~d}, J=8.2 \mathrm{~Hz}, 1 \mathrm{H}) ;{ }^{13} \mathrm{C} \mathrm{NMR}(400 \mathrm{MHz}$, $\left.\mathrm{CDCl}_{3}\right) \delta 135.5,135.0\left(\mathrm{q}, J_{\mathrm{CF}}=34.4 \mathrm{~Hz}\right), 134.0\left(\mathrm{q}, J_{\mathrm{CF}}=33.5\right.$ $\mathrm{Hz}), 129.3\left(\mathrm{q}, J_{\mathrm{CF}}=3.6 \mathrm{~Hz}\right), 124.1-123.9(\mathrm{~m}), 122.3\left(\mathrm{q}, J_{\mathrm{CF}}=\right.$ $271.9 \mathrm{~Hz}), 121.6\left(\mathrm{q}, J_{\mathrm{CF}}=272.7 \mathrm{~Hz}\right), 114.1,113.9 ;{ }^{19} \mathrm{~F} \mathrm{NMR}$ $\left(282 \mathrm{MHz}, \mathrm{CDCl}_{3}\right) \delta-62.2(\mathrm{~s}, 3 \mathrm{~F}),-63.6(\mathrm{~s}, 3 \mathrm{~F})$; HRMS-ESITOF $(\mathrm{m} / \mathrm{z})$ : $[\mathrm{M}-\mathrm{H}]^{-}$calcd for $\mathrm{C}_{9} \mathrm{H}_{2} \mathrm{~F}_{6} \mathrm{~N}, 238.0091$; found, 238.0086; FTIR (neat, $\mathrm{cm}^{-1}$ ) 2238, 1344, 1146, 1279, 1082 .

\section{Observation of trifluoromethylcopper species in ${ }^{19} \mathrm{~F}$ NMR spectrum}

To the suspension of zinc powder (without activation, $32.7 \mathrm{mg}$, $0.5 \mathrm{mmol}$, Aldrich $99.995 \%$ purity) in DMF or DMPU $(0.75 \mathrm{~mL})$, trifluoromethyl iodide (ca. $1.25 \mathrm{mmol}, 2.5$ equiv, sufficiently dissolved to the solution) was added at room temperature under argon atmosphere. After the solution was stirred for $2 \mathrm{~h}$ at room temperature, the remaining trifluoromethyl iodide was removed by bubbling argon through the solution for $15 \mathrm{~min}$. To the solution was added $\mathrm{CuI}$ (19.0 mg, $0.1 \mathrm{mmol}$ ) at room temperature. After the reaction mixture was stirred for $5 \mathrm{~min}$, the generation of cuprate species was monitored by ${ }^{19} \mathrm{~F}$ NMR analysis by using benzotrifluoride $(10 \mu \mathrm{L}$, $0.0814 \mathrm{mmol}$ ) as an internal standard and sealed capillary filled with benzene- $d_{6}$ for signal lock under argon atmosphere at room temperature. 


\section{Acknowledgements}

This research was partly supported by a grant program "Creation of Advanced Catalytic Transformation for the Sustainable Manufacturing at Low Energy, Low Environmental Load (ACT-C)" from the Japan Science and Technology Agency (JST). We thank TOSOH F-TECH, INC. for donating the trifluoromethyl iodide.

\section{References}

1. Kirsch, P. Modern Fluoroorganic Chemistry: Synthesis, Reactivity, Applications, 2nd ed.; Wiley-VCH: Weinheim, Germany, 2013. doi:10.1002/9783527651351

2. Uneyama, K. Organofluorine Chemistry; Blackwell: Oxford, U.K., 2006. doi:10.1002/9780470988589

3. Hiyama, T. Organofluorine Compounds: Chemistry and Applications; Springer-Verlag: Berlin, 2000. doi:10.1007/978-3-662-04164-2

4. Ojima, I. Fluorine in Medicinal Chemistry and Chemical Biology; Wiley-Blackwell: Chichester, U.K., 2009.

5. Furuya, T.; Kamlet, A. S.; Ritter, T. Nature 2011, 473, 470-477. doi:10.1038/nature10108

6. Jin, Z.; Hammond, G. B.; Xu, B. Aldrichimica Acta 2012, 45, 67-83.

7. Tomashenko, O. A.; Grushin, V. V. Chem. Rev. 2011, 111, 4475-4521. doi:10.1021/cr1004293

8. Nie, J.; Guo, H.-C.; Cahard, D.; Ma, J.-A. Chem. Rev. 2011, 111, 455-529. doi:10.1021/cr100166a

9. Mikami, K.; Itoh, Y.; Yamanaka, M. Chem. Rev. 2004, 104, 1-16. doi:10.1021/cr030685w

10. Burton, D. J.; Yang, Z.-Y. Tetrahedron 1992, 48, 189-275. doi:10.1016/S0040-4020(01)88139-4

11. Prakash, G. K. S.; Yudin, A. K. Chem. Rev. 1997, 97, 757-786. doi:10.1021/cr9408991

12. Prakash, G. K. S.; Mandal, M. J. Fluorine Chem. 2001, 112, 123-131. doi:10.1016/S0022-1139(01)00477-8

13. Naumann, D.; Tyrra, W.; Kock, B.; Rudolph, W.; Wilkes, B. J. Fluorine Chem. 1994, 67, 91-93. doi:10.1016/0022-1139(93)02937-A

14. Kremlev, M. M.; Tyrra, W.; Mushta, A. I.; Naumann, D.; Yagupolskii, Y. L. J. Fluorine Chem. 2010, 131, 212-216. doi:10.1016/j.jfluchem.2009.10.011

15. Prakash, G. K. S.; Jog, P. V.; Batamack, P. T. D.; Olah, G. A. Science 2012, 338, 1324-1327. doi:10.1126/science.1227859

16. Kitazume, T.; Ishikawa, N. J. Am. Chem. Soc. 1985, 107, 5186-5191. doi:10.1021/ja00304a026

17. Popov, I.; Lindeman, S.; Daugulis, O. J. Am. Chem. Soc. 2011, 133 , 9286-9289. doi:10.1021/ja2041942

18. Oishi, M.; Kondo, H.; Amii, H. Chem. Commun. 2009, 1909-1911. doi:10.1039/b823249k

19. Cho, E. J.; Senecal, T. D.; Kinzel, T.; Zhang, Y.; Watson, D. A.; Buchwald, S. L. Science 2010, 328, 1679-1681. doi:10.1126/science.1190524

20. Chu, L.; Qing, F.-L. J. Am. Chem. Soc. 2012, 134, 1298-1304. doi:10.1021/ja209992w

21. Jiang, X.; Chu, L.; Qing, F.-L. J. Org. Chem. 2012, 77, 1251-1257. doi:10.1021/jo202566h

22. Aldrich: Lot\# MKBK3648V, powder <150 $\mu \mathrm{m}, 99.995 \%$ trace metals basis.

23. Wiemers, D. M.; Burton, D. J. J. Am. Chem. Soc. 1986, 108, 832-834. doi:10.1021/ja00264a043
24. Francèse, C.; Tordeux, M.; Wakselman, C. Tetrahedron Lett. 1988, 29 , 1029-1030. doi:10.1016/0040-4039(88)85326-7

25. Hu, M.; Ni, C.; Hu, J. J. Am. Chem. Soc. 2012, 134, 15257-15260. doi:10.1021/ja307058c

26. Kütt, A.; Movchun, V.; Rodima, T.; Dansauer, T.; Rusanov, E. B.; Leito, I.; Kaljurand, I.; Koppel, J.; Pihl, V.; Koppel, I.; Ovsjannikov, G.; Toom, L.; Mishima, M.; Medebielle, M.; Lork, E.; Röschenthaler, G.-V.; Koppel, I. A.; Kolomeitsev, A. A. J. Org. Chem. 2008, 73, 2607-2620. doi:10.1021/jo702513w

27. Naumann, D.; Roy, T.; Tebbe, K.-F.; Crump, W. Angew. Chem., Int. Ed. Engl. 1993, 32, 1482-1483. doi:10.1002/anie.199314821

28. Zanardi, A.; Novikov, M. A.; Martin, E.; Benet-Buchholz, J.; Grushin, V. V. J. Am. Chem. Soc. 2011, 133, 20901-20913. doi:10.1021/ja2081026

29. Morimoto, H.; Tsubogo, T.; Litvinas, N. D.; Hartwig, J. F. Angew. Chem., Int. Ed. 2011, 50, 3793-3798. doi:10.1002/anie.201100633

30. Serizawa, H.; Aikawa, K.; Mikami, K. Chem.-Eur. J., in press.

31. Anbarasan, P.; Neumann, H.; Beller, M. Chem.-Eur. J. 2011, 17, 4217-4222. doi:10.1002/chem.201003388

32. Kondratenko, N. V.; Vechirko, E. P.; Yagupolskii, L. M. Synthesis 1980, 932-933. doi:10.1055/s-1980-29276

33. Kremlev, M. M.; Mushta, A. I.; Tyrra, W.; Yagupolskii, Y. L.; Naumann, D.; Möller, A. J. Fluorine Chem. 2012, 133, 67-71. doi:10.1016/j.jfluchem.2011.07.025

34. Ye, Y.; Sanford, M. S. J. Am. Chem. Soc. 2012, 134, 9034-9037. doi:10.1021/ja301553c

35. Knauber, T.; Arikan, F.; Röschenthaler, G.-V.; Gooßen, L. J. Chem.-Eur. J. 2011, 17, 2689-2697. doi:10.1002/chem.201002749

36. Lumma, W. C., Jr.; Hartman, R. D.; Saari, W. S.; Engelhardt, E. L.; Hirschmann, R.; Clineschmidt, B. V.; Torchiana, M. L.; Stone, C. A. J. Med. Chem. 1978, 21, 536-542. doi:10.1021/jm00204a007

\section{License and Terms}

This is an Open Access article under the terms of the Creative Commons Attribution License (http://creativecommons.org/licenses/by/2.0), which permits unrestricted use, distribution, and reproduction in any medium, provided the original work is properly cited.

The license is subject to the Beilstein Journal of Organic Chemistry terms and conditions:

(http://www.beilstein-journals.org/bjoc)

The definitive version of this article is the electronic one which can be found at: $\underline{\text { doi:10.3762/bjoc. } 9.277}$ 